\title{
The insulin-like growth factor axis and collagen turnover during prednisolone treatment
}

\author{
Ole D Wolthers, Anders Juul, Michael Hansen, Jørn Müller, Søren Pedersen
}

\begin{abstract}
Serum concentrations of insulin-like growth factor I (IGF-I) and insulin-like growth factor binding protein 3 (IGFBP3), the carboxyterminal propeptide of type I collagen (PICP), the carboxyterminal pyridinoline crosslinked telopeptide of type I collagen (ICTP), and the aminoterminal propeptide of type III procollagen (PIIIN) were studied in 10 prepubertal children with asthma (mean age 9.0 years). The children were treated with 2.5 and $5.0 \mathrm{mg} /$ day prednisolone in a randomised double blind crossover trial with run in, treatment, and washout periods of two weeks.

No statistically significant effects on serum concentrations of IGF-I and IGFBP-3 were found. Dose related reductions of PICP, ICTP, and PIIINP were observed: the mean (SEM) reduction in PICP was $33.4(26.3)$ and $68.4(20.6)$ $\mu \mathrm{g} / 1$, in ICTP $2.5(0.5)$ and $2.9(0.6) \mu \mathrm{g} / 1$, and in PIIINP $2 \cdot 1(0.7)$ and $3.1(1.8) \mu g / 1$ during the 2.5 and $5.0 \mathrm{mg}$ prednisolone periods respectively.

Short term treatment with low daily doses of prednisolone is associated with suppression of serum markers of type I and III collagen turnover in children with asthma. Intermediate and long term effects remain to be studied.

(Arch Dis Child 1994; 71: 409-413)
\end{abstract}

Growth retardation is a well known risk of systemic glucocorticosteroid treatment in children. ${ }^{1}$ The pathophysiological mechanisms causing this effect are poorly understood. The overall secretion of growth hormone appears to be unaffected by systemic treatment with glucocorticosteroids, whereas the pulsatile profile of growth hormone secretion may be attempts to elucidate the mechanisms of glucocorticosteroid induced growth suppresion.

Growth, however, requires synthesis of collagen. Type I collagen is the most abundant collagen type in connective tissues and accounts for more than $90 \%$ of the organic matrix of bone. ${ }^{12}$ Type III collagen is present in dense and loose connective tissues throughout the body. ${ }^{13}$ The serum marker of type I collagen synthesis, the carboxyterminal propeptide of type I collagen (PICP), is decreased during glucocorticosteroid treatment in adults ${ }^{14}$ and in children. ${ }^{16-18}$ In adults glucocorticosteroids have also been found to reduce serum concentrations of the marker of degradation of type I collagen, serum carboxyterminal pyridinoline crosslinked telopeptide of type I collagen (ICTP) ${ }^{1519}$ and of the marker of type III collagen synthesis, the aminoterminal propeptide of type III procollagen (PIINP). ${ }^{14}$

At present there are no evaluations of dose related effects of exogeneous glucocorticosteroids on any of these parameters in children. The aim of this study was to evaluate whether prednisolone by mouth in doses of 2.5 and 5 $\mathrm{mg} /$ day has any adverse effects on serum concentrations of IGF-I, IGFBP-3, and the markers of collagen turnover PICP, ICTP, and PIINP in children.

Patients and methods

The protocol was part of a clinical study of the influence of glucocorticosteroids by mouth on lower leg growth. ${ }^{1}$

\section{PATIENTS}

The table gives the demographic characteristics of the 10 children who participated in the study. The children were outpatients in a secondary referral centre. All had mild asthma requiring only treatment as needed with inhaled $\beta_{2}$ stimulants. None had received glucocorticosteroids either inhaled or by mouth within two months before the study, and no other drug was taken during the study period. All children were prepubertal. The study was approved by the local ethical committee and informed consent was given by all children and their parents.

Characteristics of the study groups. Values are mean (range)

\begin{tabular}{lc}
\hline No of boys (girls) & $8(2)$ \\
Age (years) & $9 \cdot 0(7-11)$ \\
Height SD score & $0 \cdot 18(-1 \cdot 19$ to $2 \cdot 72)$ \\
Weight (kg) & $29 \cdot 6(23 \cdot 0-35 \cdot 6)$ \\
Body surface area $\left(\mathrm{m}^{2}\right)$ & $1 \cdot 03(0 \cdot 97-1 \cdot 20)$ \\
Duration of asthma (years) & $3(1-6)$ \\
\hline
\end{tabular}
\footnotetext{
influenced. ${ }^{2}$ The primary growth promoting effects of growth hormone are mediated by insulin-like growth factor I (IGF-I). ${ }^{3}$ Most of the circulating IGF-I is bound to specific IGF binding proteins (IGFBPs), of which the growth hormone dependent IGFBP-3 is the most important. IGFBP-3 is thought to modulate the bioavailability of IGF-I by increasing the biological half life $\mathrm{e}^{4}$ and by decreasing the transendothelial transport of IGF-I. ${ }^{5}$ Experimental data have shown both stimulatory and inhibitory effects of IGFBPs on IGF bioactivity at the cellular level. ${ }^{6-10}$ Clinical observations support the hypothesis that circulating IGFBPs modulate the activity of IGFs. ${ }^{11}$ Therefore, measurements of both

IGF-I and IGFBP-3 may be valuable in

Correspondence to: Wolthers, Siriusvej Accepted 16 June 1994

Department of Hvidovre Hospital, Denmark

M Hansen

Paediatrics, Kolding

Hospital, Kolding

Department of Growth and Reproduction Rigshospitale A Juul

J Müller
} 
DESIGN

The study was a randomised double blind crossover trial with five periods of two weeks duration. In period 1 (run in) and periods 3 and 5 (washout) placebo was given, and in periods 2 and 4 the children received prednisolone. Prednisolone was given as 2.5 and $5.0 \mathrm{mg} /$ day in divided doses at $7.30 \mathrm{am}$ and $7 \cdot 30 \mathrm{pm}$. Treatment order was allocated by a computerised randomisation scheme prepared in balanced blocks. The prednisolone tablets, identical in size and appearance, were delivered in identical boxes.

\section{SERUM ANALYSES}

IGF-I, IGFBP-3, and markers of collagen metabolism were assessed at day 14 in period 1 (run in) and periods 2 and 4 (treatment periods). Blood samples were taken at roughly the same time (that is, within one hour) in the afternoon (between 3 and $6 \mathrm{pm}$ ). The samples were centrifuged at $3000 \mathrm{rpm}$ for 10 minutes within one hour after they were taken Serum was frozen and stored at $-20^{\circ} \mathrm{C}$ and batch assayed at the completion of the study.

IGF-I was analysed by a specific radioimmunoassay as previously described, ${ }^{20}$ with some modifications. ${ }^{21}$ Serum was extracted by acid/ethanol and cryoprecipitated before analysis to remove interfering binding proteins. A monoiodinated isomer of the truncated IGF-I (Tyr31-des(1-3)IGF-1) was used as radioligand. Interassay and intra-assay variations were $8.7 \%$ and $3.9 \%$ (at a bound/free ratio (B/BO) of $0 \cdot 40)$.

IGFBP-3 was determined by a specific radioimmunoassay originally described by Blum et al. ${ }^{22}$ Materials for the assay were obtained from Mediagnost $\mathrm{GmbH}$ (Tübingen, Germany). Interassay and intra-assay variations were $10 \cdot 0 \%$ and $7 \cdot 2 \%$ (at $\mathrm{B} / \mathrm{BO} 0 \cdot 40$ ). Normal serum ranges for IGF-I and IGFBP-3 in children have been provided (unpublished data). ${ }^{21}$

Serum concentrations of PICP and PIINP were determined by radioimmunoassays based on human antigen (PICP-RIA-kit and PIINPRIA-kit, Orion Diagnostica, Finland). ${ }^{12-14} 23$ The interassay and intra-assay variations were $10.0 \%$ and $10.0 \%$ for PICP determinations (at $\mathrm{B} / \mathrm{BO} 0.33$ ) and $8.0 \%$ and $7 \cdot 2 \%$ respectively for PIIINP (at B/BO 0.43).

The serum carboxyterminal pyridinoline crosslinked telopeptide of type I collagen was determined by specific radioimmunoassay (ICTP-RIA-kit, Orion Diagnostica, Finland) as described by Risteli et al. ${ }^{19}$ The interassay and intra-assay variations were 5.9 and $5 \cdot 2 \%$ (at B/BO 0.39). Normal serum ranges for PICP and PIINP have been published elsewhere. ${ }^{24}$ The range for serum ICTP in 20 healthy prepubertal children aged 5-14 years (mean 10.0 years) was 6.4-19.8 $\mu \mathrm{g} / \mathrm{l}$ (mean (SEM) $12.9(0 \cdot 7) \mu \mathrm{g} / \mathrm{l})$.

\section{STATISTICAL ANALYSIS}

To be able to compare IGF-I, IGFBP-3, PICP, and PIINN with normal reference values, SD scores were calculated by the following equation: (observed value-mean)/1 SD. Age and sex related means and SDs from normal children were used (unpublished data). ${ }^{21} 24$ As good normative data were not available for comparisons of the ICTP data they are presented as raw data.

The data for each parameter during run in and treatment periods were compared by the method described for crossover trial designs. ${ }^{25}$ Neither a period nor carryover effect was found. Page's test for trend was used to evaluate if there was any dose related effects of the treatments. ${ }^{26}$ The $5 \%$ level was considered significant.

\section{Results}

There were five children in each blinded dose sequence group.

The run in SD scores (SEM) for IGF-I, IGFBP-3, PICP, and PIIINP were $-0.6(0.2)$, $+0.7(0.3),-0.1(0.2)$, and $-0.5(0.2)$ respectively. None of these parameters differed significantly from zero. The ICTP concentrations were $6.6-12 \cdot 2 \mu \mathrm{g} / 1$ (mean (SEM) 9.7 $(0 \cdot 5))$ - that is, within the range determined in healthy children.

Figure 1 shows the individual serum concentrations of IGF-I and IGFBP-3 during run in and at each dose of prednisolone. The mean (SEM) increase in IGF-I during
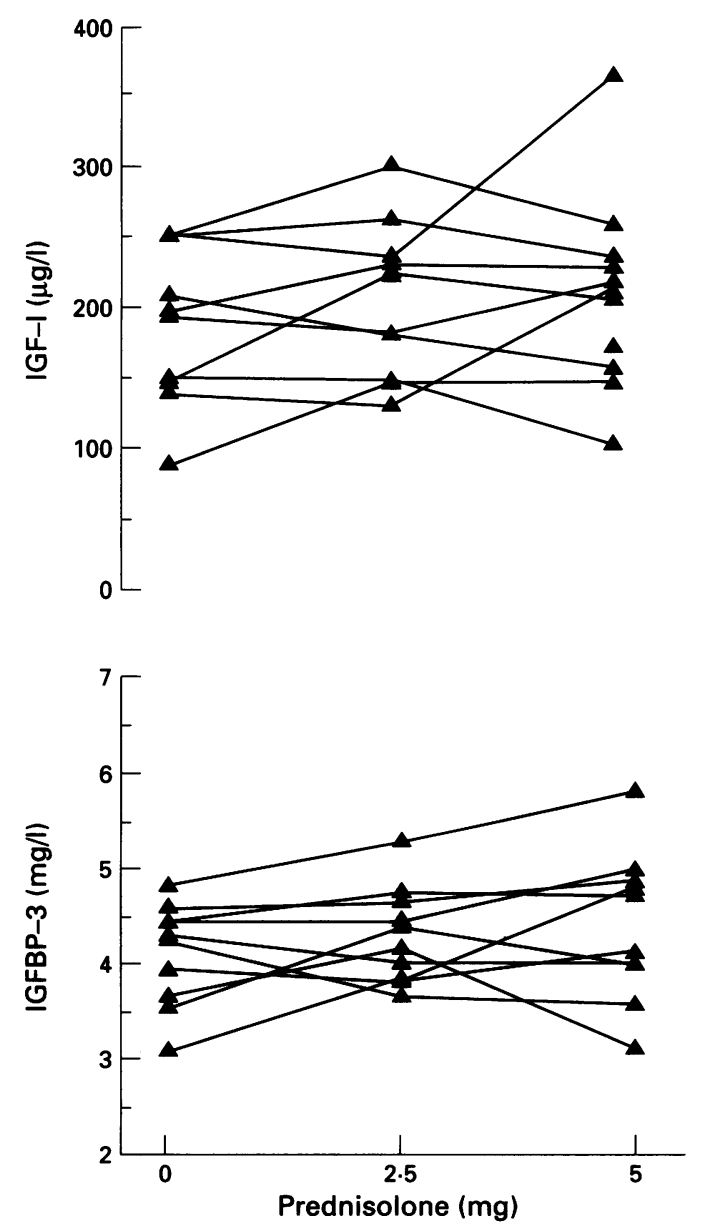

Figure 1 Serum concentrations of IGF-I and IGFBP-3 in 10 children with asthma before treatment and at each double blinded dose level of prednisolone $(2 \cdot 5$ and $5 \cdot 0$ mg/day). No statistically significant variation was found. 
treatment with 2.5 and $5.0 \mathrm{mg}$ prednisolone was $18.1(11.3)$ and $28.9(16.9) \mu \mathrm{g} / 1$ respectively $(\mathrm{p}=0.37 ; \mathrm{z}=0.9)$. The concentration of IGFBP-3 was increased with 203.4 (144.0) and $31.8 .5(195.6) \mu \mathrm{g} / \mathrm{l}$ during the two dose levels $(p=0 \cdot 12 ; z=1 \cdot 6)$.

Figure 2 shows the individual serum concentrations of the markers of collagen turnover. The mean (SEM) reduction in PICP during treatment with 2.5 and $5.0 \mathrm{mg}$ prednisolone was $33.4(26.3)$ and $68.4(20.6) \mu \mathrm{g} / \mathrm{l}$ respectively $(p=0 \cdot 04 ; z=-2 \cdot 0)$. The concentration of ICTP was reduced with $2.5(0 \cdot 5)$
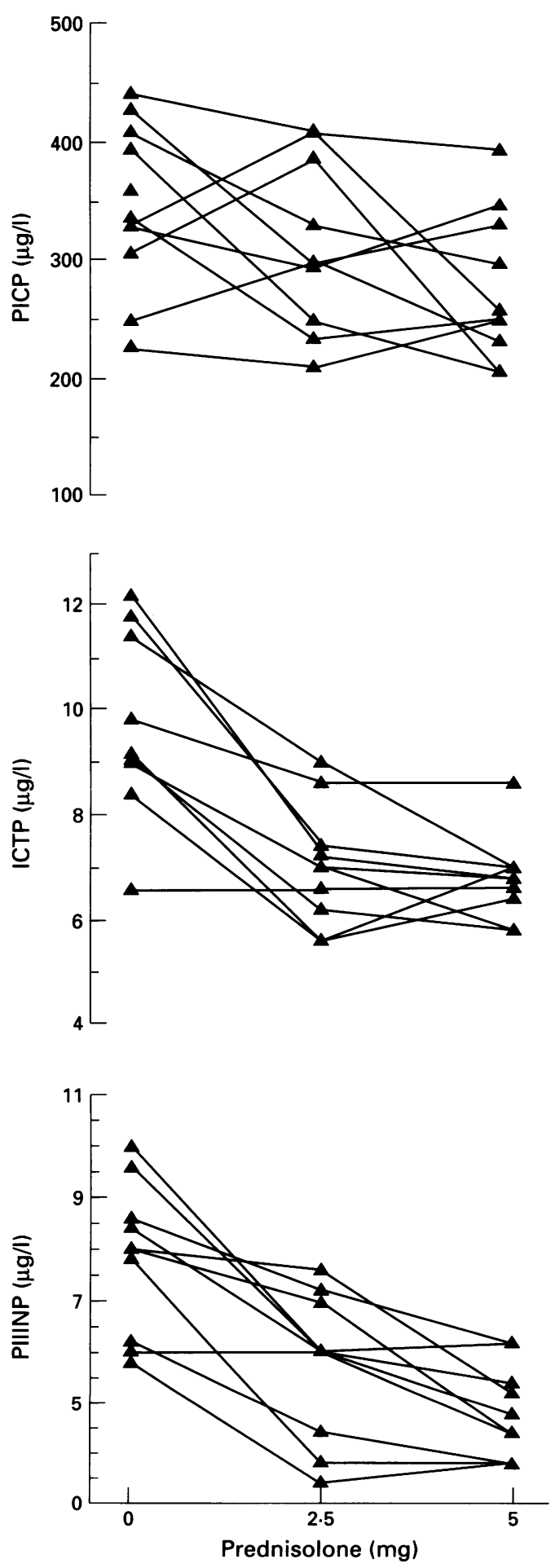

Figure 2 Serum concentrations of PICP, ICTP, and PIIINP in 10 children with asthma before treatment and at each double blind dose level of prednisolone $(2.5$ and 5.0 $\mathrm{mg} /$ day). $A$ dose related reduction of all three parameters was found: $p=0.04, p<0.001$, and $p<0.001$ respectively. and $2.9(0.6) \mu \mathrm{g} / \mathrm{l}(\mathrm{p}<0.001 ; \mathrm{z}=-3.9)$ and PIIINP with $2 \cdot 1(0 \cdot 7)$ and $3 \cdot 1(1 \cdot 8) \mu \mathrm{g} / 1$ $(p<0.001 ; z=-4.0))$ during the 2.5 and $5.0 \mathrm{mg}$ prednisolone periods respectively.

\section{Discussion}

Serum concentrations of total IGF-I and IGFBP-3 are indirect measures of the growth stimulating activity of free IGF-I (IGF-I activity). Attempts to measure free IGF-I have presented methodological problems and the exact relation between variations in serum concentrations of IGF-I, IGFBP-3, and IGF-I activity has not been established. Treatment with systemic glucocorticosteroids seems to be associated, however, with reduced IGF-I activity that is not accounted for by decreased IGF-I serum concentrations. ${ }^{10}$ Concentrations of IGF-I appear to be normal or increased during periods of glucocorticosteroid excess and may increase during exogeneous administration. ${ }^{1017}$ These findings suggest that glucocorticosteroid treatment does not impair IGF-I production in children but, rather, may antagonise IGF-I action by direct or indirect inhibitory mechanisms. The present observations of numerically increased IGFBP-3 concentrations during prednisolone treatment, though not statistically significant, are in keeping with the hypothesis that glucocorticosteroid treatment may be associated with increased concentrations of IGFBP-3, which may inhibit IGF-I activity. ${ }^{11} 27$ These data emphasise the need for further evaluations of the effect of glucocorticosteroid treatment in larger populations of children focusing on the ratio between IGF-I and IGFBP-3 and the relation to growth velocity.

Variations in serum concentrations of PICP and ICTP reflect fluctuations in synthesis and degradation, respectively, of type I collagen primarily in bone. 12192428 Concentrations of PIIINP reflect the synthesis of type III collagen in connective tissues throughout the body. ${ }^{1324}$ Inflammation may be associated with increased serum concentrations of PIIINP that correlate with disease severity. ${ }^{29}$ Concentrations of PICP are decreased in inflammatory diseases such as rheumatoid arthritis, whereas ICTP may be increased. ${ }^{15}$ The run in values of PICP, ICTP, and PIIINP in this group of children with mild asthma with normal pulmonary function did not differ significantly from the values in normal children. Therefore, it seems unlikely that the suppressive effect of prednisolone on the markers of collagen turnover could reflect any anti-inflammatory effect of the drug. Furthermore, animal studies have shown that exogeneous glucocorticosteroids do not affect the hepatic clearance rate of procollagen propeptides (unpublished data). Finally, glucocorticosteroids have long been known to suppress the synthesis of interstitial procollagens in vitro and in normal adults. ${ }^{30} 31$ The observed reductions in serum concentration of PICP, ICTP, and PIIINP must therefore reflect the catabolic effect of prednisolone. 
Simultaneous assessment of PICP and ICTP make it possible to estimate the balance between type I collagen synthesis and degradation in children treated with glucocorticosteroids. When coupling between the two activities is effective they should be changed into the same direction. The present findings of reduced values of the two parameters suggest that exogeneous glucocorticosteroids cause an inhibition of type I collagen turnover which is reset in a suppressed steady state condition. That is in accordance with our report that prednisolone suppresses bone turnover, as indicated from the finding of a reduction in serum osteocalcin concentrations and urinary excretion of hydroxyproline. ${ }^{32}$ To some extent this may explain the marked growth suppressive effects of prednisolone. ${ }^{1}$ That interpretation is supported by previous findings of low values of PICP and subnormal growth in children treated with glucocorticosteroids $^{16}$ and by observations of correlation between serum concentrations of PICP and PIINN and height growth velocity in normal children. 24 33-36

The dose related suppressive effect of $2 \cdot 5$ and $5 \mathrm{mg}$ prednisolone on the markers of collagen turnover was not reflected in the short term growth data of the children. ${ }^{1}$ The lower leg length measurements did not discriminate between the suppressive effect of the two doses. This may suggest that a maximum effect on short term lower leg growth may have been reached within the dose range assessed or, perhaps, to some extent limitations in the knemometry technique may confound the growth results when the effects of systemic doses of glucocorticosteroids are studied. ${ }^{1}$

When taken together, however, these data suggest that PICP, ICTP, and PIINNP could be useful chemical adjuncts to anthropometric techniques in the assessment of the risk of growth suppressive effects of exogeneous glucocorticosteroids in children. Intermediate and long term studies are needed to evaluate this.

1 Wolthers OD, Pedersen S. Short term linear growth in asthmatic children during treatment with prednisolone. BMF 1990; 301: 145-8.

2 Miell JP, Corder R, Pralong FP, Gaillard RC. Effects of dexmethasone on growth hormone (GH)-releasing hormone, arginine- and dopaminergic stimulated GH secretion and total plasma insulin-like growth factor-I concentrations in normal male volunteers. $f$ Clin Endocrinol Metab 1991; 72: 675-81.

3 Sara VR, Hall K. Insulin-like growth factors and their binding proteins. Physiol Rev 1990; 70: 591-614.

4 Guler HP, Zapf J, Schmid C, Frösch ER. Insulin-like growth factors I and II in healthy man. Estimations of half-lives and production rates. Acta Endocrinol (Copenh) 1989; 121: 753-8.

5 Bar RS, Clemmons DR, Boes M, et al. Transcapillary permeability and subendothelial distribution of endothelial and amniotic fluid insulin-like growth factor binding and amniotic fluid insulin-like growth factor binding
proteins in the rat heart. Endocrinology 1990; 127: proteins

6 Blum WF, Jenne EW, Reppin F, Kietzmann K, Ranke MB, Bierich JR. Insulin-like growth factor-I (IGF-I)-binding protein complex is a better mitogen than free IGF-I. Endocrinology 1989; 125: 766-72.

7 Elgin RG, Busby WH Jr, Clemmons DR. An insulin-like growth factor (IGF) binding protein enhances the biologic response to IGF-I. Proc Natl Acad Sci USA 1987; 84: 3254-8.

8 Ernst $M$, Rodan GA. Increased activity of insulinlike growth factor (IGF) in osteoblastic cells in the presence of growth hormone (GH): positive correlation with the presence of the GH-induced IGF-binding protein BP-3. Endocrinology 1990; 127: 807-14

9 Mohan S, Bautista CM, Wergedal J, Baylink DJ. Isolation of an inhibitory insulin-like growth factor (IGF) binding protein from bone cell-conditioned medium: a potential local regulator of IGF action. Proc Natl Acad Sci USA 1989; 86: 8338-43.

10 Miell JP, Taylor AM, Jones J, et al. The effects of dexamethasone treatment on immunoreactive and bioactive insulin-like growth factors (IGFs) and IGF-binding proteins in normal male volunteers. $\mathcal{f}$ Endocrinol 1993; proteins in nom

11 Blum WF, Ranke MB, Kietzmann K, Tönshoff B, Mehl O. Growth hormone resistance and inhibition of somatomedin activity by excess of insulin-like growth factor binding protein in uremia. Pediatr Nephrol 1991; 5: 539-44.

12 Melkko J, Niemi S, Risteli L, Risteli J. Radioimmunoassay of the carboxyterminal propeptide of human type procollagen. Clin Chem 1990; 36: 1328-32.

13 Risteli J, Niemi S, Trivedi P, Mäentausta O, Mowat AP, Risteli L. Rapid equilibrium radioimmunoassay for the amino-terminal propeptide of human type III procollagen Clin Chem 1988; 34: 715-8.

14 Oikarinen A, Autio P, Vuori J, et al. Systemic glucocorticoid treatment decreases serum concentrations of carboxyterminal propeptide of type I procollagen and aminoterminal propeptide of type III procollagen. Br $\mathcal{f}$ Dermatol 1992; 126: 172-8.

15 Hansen M, Horslev-Petersen K, Stoltenberg M, Lorenzen I, Risteli L, Risteli J. Type I collagen metabolism in rheumatoid arthritis. Effects of a single pulse of methylprednisolone [Abstract]. Br ₹ Rheumatol 1992; 31 (suppl 2): 129 .

16 Hyams JS, Moore RE, Leichtner AM, Carey DE, Goldber BD. Relationship of type I procollagen to corticosteroid therapy in children with inflammatory bowel disease. f Pediatr 1988; 112: 893-8.

17 Allen DB, Goldberg BD. Stimulation of collagen synthesis and linear growth by growth hormone in glucocorticoidtreated children. Pediatrics 1992; 89: 416-21.

18 Sorva $R$, Turpeinen $M$, Juntunen-Backman $K$, Karonen SL, Sorva A. Effects of inhaled budesonide on serum markers of bone metabolism in children with asthm f Allergy Clin Immunol 1992; 90: 808-15.

19 Risteli J, Elomaa I, Niemi S, Novamo A, Risteli I. Radioimmunoassay for the pyridinoline cross-linked carboxyterminal telopeptide of type I collagen: a new serum marker of bone collagen degradation. Clin Chem 1993; 39: 635-40.

20 Bang P, Eriksson U, Sara V, Wivall IL, Hall K. Comparison of acid ethanol extraction and acid gel filtration prior to IGF-I and IGF-II radioimmunoassays: improvement of determinations in acid ethanol extracts by the use of truncated IGF-I as radioligand. Acta Endocrinol (Copenh) 1991; 124: 620-9.

21 Juul A, Bang P, Hertel NT, et al. Serum insulin-like growth factor-I in 1030 healthy children, adolescents, and adults, relation to age, sex, stage of puberty, testicular size and body mass index. F Clin Endocrinol Metab 1994; 78: 744-52.

22 Blum WF, Ranke MB, Kietzmann K, Gauggel E, Zeisel HJ, Bierich JR. A specific radioimmunoassay for the growth hormone (GH)-dependent somatomedin-binding protein: its use for diagnosis of GH deficiency. $\mathcal{F}$ Clin Endocrinol Metab 1990; 90: 1292-8.

23 Oikarinen A, Autio P, Urpo K, Risteli L, Risteli J. A new method to measure type I and III collagen synthesis in human skin in vivo: demonstration of decreased collagen synthesis after topical glucocorticoid treatment. F Invest Dermatol 1992; 98: 220-5.

24 Hertel NT, Stoltenberg M, Juul A, et al. Serum concentrations of type I and III procollagen propeptides in healthy ins of the 1 and $1 \mathrm{i}$ procollagen propeptides in healthy treatment with gonadotropin-releasing hormone analog and cyproterone acetate. $\mathcal{f}$ Clin Endocrinol Metab 1993; 76: $924-7$.

25 Hills M, Armitage B. The two-period cross-over clinical trial. Br f Clin Pharmacol 1977; 8: 7-20.

26 Hollander M, Wolfe DA. Nonparametrical statistical methods. New York: Wiley, 1973: 147-50.

27 Martin JL, Baxter RC. Insulin-like growth factor binding protein-3: biochemistry and physiology. Growth Regul 1992; 2: 88-9.

28 Parfitt AM, Simon LS, Villanueva AR, Krane $M$. Procollagen type I carboxy-terminal extension peptide in serum as a marker of collagen biosynthesis in bone. Correlation with iliac bone formation rates and comparison with total alkaline phosphatase. $\mathcal{f}$ Bone Mineral Res 1987; 2: 427-36.

29 Horslev-Petersen K. Circulating extracellular matrix components as markers for connective tissue response to ponents as markers for connective tissue response to
inflammation [Thesis]. Copenhagen: Laegeforenings forlag, 1990 .

30 Oikarinen AI, Uitto J, Oikarinen J. Glucocorticoid action on connective tissue: from molecular mechanisms to clinical practice. Med Biol 1986; 64: 221-30.

31 Cutroneo KR, Rokowski R, Counts DF. Glucocorticoids and collagen synthesis: comparison of in vivo and cellcultures. Collagen Rel Res 1981; 1: 557-68.

32 Wolthers OD, Riis BJ, Pedersen S. Bone turnover in asthmatic children treated with oral prednisolone or inhaled budesonide. Pediatr Pulmonol 1993; 16: 341-6.

33 Carey DE, Goldberg B, Ratzan SK, Rubin KR, Rowe DW. Radioimmunoassay for type I procollagen in growth hormone-deficient children before and during treatment with growth hormone. Pediatr Res 1985; 19: 8-11. 
34 Danne T, Grüters A, Schuppan D, Quantas N, Enders I, Weber B. Relationship of procollagen type III propeptiderelated antigens in serum to somatic growth in healthy children and patients with growth disorders. 7 Pediatr 1989; 114: 257-60.

35 Trivedi P, Hindmarsh P, Risteli J, Risteli L, Mowat AP, Brook CGD. Growth velocity, growth hormone therapy, and serum concentrations of the amino-terminal propeptide of type III procollagen. $\mathcal{F}$ Pediatr 1989; 114: 225-30. 36 Trivedi P, Risteli J, Risteli L, Hindmarsh PC, Brook CGD, Mowat AP. Serum concentrations of the type I and III procollagen propeptides as biochemical markers of growth procollag in propeptides as disorders. Pediatr Res 1991; 30: 276-80.

\section{Neonatal screening for toxoplasmosis}

It is possible that screening newborn babies for toxoplasmosis and treating those with confirmed congenital infection might stop some of them getting later eye, ear, or brain disease. A screening programme using the heelprick filter paper blood samples collected for routine biochemical screening and testing for IgM antibodies to toxoplasma was begun in Massachusetts in 1986 and in New Hampshire in 1988 (Nicholas G Guerina and colleagues, New England Fournal of Medicine 1994; 330: 1858-63). Up to July 1992 some 645000 babies were screened. One hundred tests were positive but on further investigation only 50 babies were shown to have congenital infection. All of these 50 were normal on routine neonatal examination but nine had retinal lesions on ophthalmological assessment.

Five babies with severe toxoplasma brain disease were identified independently of the screening programme. Only two of these had a positive IgM antibody screening test.

Forty six children completed a 12 month course of treatment with pyrimethamine, leucovorin, and either sulphadiazine or spiramycin. Thirteen had anaemia, neutropenia, or both during treatment, one developed a rash, and one was inadvertently given an excessive dose of pyrimethamine. Four children apparently developed new retinal lesions on or following treatment. As there was no untreated group the effectiveness of the treatment is not known. It is suggested that these children did well in comparison with those in previous follow up studies of untreated children.

The screening test, therefore, was negative in $60 \%$ of children with grossly symptomatic congenital infection and $50 \%$ of positive tests were apparently false positives. Treatment is not devoid of problems and whether it is effective is uncertain. There seems to be a lot more work to be done before the authors' (muted) enthusiasm is likely to be shared by many.

ARCHIVIST 